\title{
Research on Disciplinary Measures of Dishonesty Against the Person Subject to Enforcement Under Chinese Civil Law
}

\author{
Chen Jiandong ${ }^{1,}$, , Jiang Zhengxiong ${ }^{1}$, Wang Deling ${ }^{2}$, Ni Zhangfeng ${ }^{3}$ \\ ${ }^{1}$ Law School, Shanghai Maritime University, Shanghai, China \\ ${ }^{2}$ Merchant Marine College, Shanghai Maritime University, Shanghai, China \\ ${ }^{3}$ Shanghai Maritime Safety Administration, Shanghai, China
}

Email address:

winstonchenjd@163.com (Chen Jiandong), zxjiang@shmtu.edu.cn (Jiang Zhengxiong), dlwang@shmtu.edu.cn (Wang Deling), 77442070@qq.com (Ni Zhangfeng)

*Corresponding author

\section{To cite this article:}

Chen Jiandong, Jiang Zhengxiong, Wang Deling, Ni Zhangfeng. Research on Disciplinary Measures of Dishonesty Against the Person Subject to Enforcement Under Chinese Civil Law. International Journal of Law and Society. Vol. 4, No. 3, 2021, pp. 209-218. doi: $10.11648 /$ j.ijls.20210403.18

Received: August 2, 2021; Accepted: August 23, 2021; Published: September 10, 2021

\begin{abstract}
Since 2013, through including the people subject to enforcement in the list of dishonest persons and restricting their high consumption, the Supreme People's Court has played a positive role in urging those dishonest people to actively fulfill their civil legal obligations. The disciplinary measures against dishonesty affect every aspect in the daily activities of civil subjects. In this paper, the author adopt literature research on the provisions of disciplinary measures for dishonesty. Through literature research, this paper clarified the scope of the object for dishonest punishment, the specific measures of the dishonest punishment, and the current relief methods. At the same time, we also found the circumstances such as the legal system of disciplinary measures for dishonest is not complete, the provisions of relief channels need to be improved, lack of restrictions on civil rights of dishonest persons subject to enforcement among the punishment measures and lack the restrictions on foreigners among those dishonest person subject to enforcement. In this paper, by concluded in combination with other discussions, it is suggested to formulate a special "Social Dishonest Punishment Law", and the enforcement court of the people's court should be responsible for reviewing of the correction application of the dishonest persons. In addition, restrictions on certain rights of the dishonest persons subject to enforcement in the civil litigation and foreign people subject to enforcement against dishonest should be restricted from entering China or applying for permanent residence in China should also be included in the dishonest measures.
\end{abstract}

Keywords: Person Subject to Enforcement, Disciplinary Measures Against Dishonesty, Chinese Civil Law

\section{Overall of Disciplinary Measures of Dishonesty Against the Person Subject to Enforcement}

Abiding by and fulfilling the obligations determined by the effective civil legal documents is the duty for the civil subject. Refusing to perform the obligations determined by the effective legal documents happens frequently in the society, which directly affects the society's doubt on the executive efficiency of the valid legal documents and leads to the difficulty of enforcement. The "Civil Procedure Law" specifically stipulates that the people's court may take records in the credit information system, publish the information of non-performance of obligations through the media and other measures stipulated by law for the executor who fails to perform the obligations determined in the legal documents. According to the regulation, the Supreme People's Court, the National Development and Reform Commission and other departments have jointly established a disciplinary mechanism for the list of dishonest executors, taking restrictive measures in all aspects of social life for 
those executors who refuse to fulfill their obligations as determined by legal documents, and urging them to take the initiative to perform their obligations as determined in the judgment documents. Since the implementation of the mechanism, as of July 7, 2021, there are 6,612,813 people who have been announced to be dishonest in the whole country, which does not include the situation that they have already fulfilled their judgment obligations and withdrawn from the list of dishonest persons and the same person who has been executed has been repeatedly counted due to different cases. Therefore, the actual number of dishonest persons should be greater than this number. In the case of "being dishonesty in one place and being restricted in everywhere", as of March 2019, 3,660,000 people were forced by disciplinary pressure to fulfill their obligations automatically. In the year of 2020, a total of 2,083,000 cases of dishonesty were deleted in time by courts all over our country, up increase $19.3 \%$ within the same period. From the above data, it can be seen that the disciplinary measures for breach of trust of the enforced person play an important role in urging the executors to fulfill the legal judgment obligation. This paper will discuss on the shortcomings and improvement measures for the object, content, relief ways of the disciplinary measures for dishonesty.

\section{Object of Disciplinary Measures for Dishonesty}

According to the provisions of the "Civil Procedure Law", the object of the disciplinary measures for dishonesty is the person subject to enforcement who refuses to perform the legal documents and other measures prescribed by law. The person subject to enforcement refers to the party who fails to perform the court judgment or arbitral award after the expiration of the statutory appeal or after the final judgment is made, and enters the enforcement procedure.

\subsection{The Person Subject to Enforcement Refers to the Party Who Is Determined by the Effective Civil Legal Documents to Perform Its Legal Obligations}

\subsubsection{The Parties Involved the Civil Legal Relationship}

Cases can be divided into three types according to their nature: criminal, civil and administrative. All types of cases are regulated by their corresponding substantive and procedural laws. The "Civil Procedure Law" [1] regulates the activities of civil subjects in civil litigation, as a system in the execution procedure of civil litigation, the disciplinary measures for dishonesty of the executors are only applicable to civil subjects. Civil subjects are classified as natural persons, legal persons and unincorporated organizations in the Civil Code [2]. Natural persons are divided into people with full capacity, limited capacity and without capacity according to their capacity. Adults are over 18 years old, minors are under 18 years old. Adults who can identify their own behavior should have full capacity for civil conduct. For personnel who is over 16 years old and takes his own labor income as the main source should be regarded as the person with full capacity. Minors over eight years old are persons with limited capacity for civil conduct, and their civil legal act should be represented by their legal representatives or agreed and recognized by their legal representatives. However, it is possible to independently carry out civil legal acts that are purely profitable or civil legal acts that are suitable for their age and intelligence. For people who cannot to recognize their own behavior and the minors under the age of 8 are persons without capacity for civil conduct. At the same time, there are two special subjects among natural persons, individual business and individual peasant households. Individual business refers to natural persons who are legally registered to engage in industrial and commercial operations. Individual peasant households refer to members of rural collective economic organizations, who have obtained the right to contracted management of rural land according to law and engaged in household contracted management. Individual industrial and commercial households are more common in cities, while individual peasant households only exist in rural areas. These two types of subjects are the products of the reform and opening up policy, with strong Chinese characteristics. They have the characteristics of commercial subjects, but are different from traditional commercial subjects. Their debts are ultimately borne by the natural persons who set up individual industrial and commercial households or contracted rural households, so they are classified as natural persons.

Legal person refers to an organization with the capacity for civil rights and conduct, and independently enjoys civil rights and assumes civil obligations according to law. The legal person are divided into profit-making legal persons, nonprofit legal persons and special legal persons in the "Civil Code". Profit-making legal person refers to a legal person established for the purpose of obtaining profits and distributing them to shareholders and other investors, including limited liability companies, joint stock limited companies and other enterprise legal persons. Enterprise legal person is engaged in production, circulation, science and technology and other activities, aiming at making profits, increasing accumulation and creating social wealth. It is a kind of operational social and economic organization. Nonprofit legal person: a legal person established for public welfare purposes or other non-profit purposes, which does not distribute the profits obtained to investors, founders or members. The special legal person refers to the government legal person, rural collective economic organization legal person, urban and rural cooperative economic organization legal person and grass-roots mass autonomous organization legal person.

An unincorporated organization is an organization without legal personality, but can engage in civil activities in its own name according to law. Unincorporated organizations include sole proprietorship enterprises, partnership enterprises, professional service organizations without legal personality and others.

The "Civil Code" stipulates that whether the above three 
categories of civil subjects can become civil litigants should also be judged according to whether they have the capacity for civil conduct and civil litigation rights. Capacity for civil conduct is the qualification of civil subjects to obtain civil rights and undertake civil obligations by their own actions. [3] For people who is able to enjoy civil litigation rights and undertake civil litigation obligations should have the qualification to become the party with civil litigation. There are differences and connections between them. People do not have the capacity for civil conduct, thus lack of the capacity for civil litigation rights. The "Civil Procedure Law" stipulates that citizens, legal persons and other organizations are the subjects of civil litigation. People with full capacity for civil conduct in civil litigation and legal person organizations, as subjects with full capacity for civil conduct, have the qualification to independently undertake civil obligations, and of course should have the capacity for litigation and can become parties to civil litigation. The judicial interpretation of the "Civil Procedure Law" lists seven specific subjects and eight general lists of other organizations, including sole proprietorship enterprises and partnership enterprises. Therefore, combined with the above provisions, the author believes that unincorporated organizations can also be used as civil litigants. Whether a person with no capacity for civil conduct, a person with limited capacity for civil conduct, or a party to a civil lawsuit is still disputed. Article 133 of the "General Principles of the Civil Law" before the implementation of the "Civil Code" stipulates: "If a person has no civil capacity or a person with limited civil capacity causes damage to others, the guardian should bear the civil liability." At the same time, these two types of subjects are considered to be incapable of litigation because of their lack of capacity for civil rights. In practice, there are three different views on the qualifications of civil litigants of these two types of subjects. [4] The first view lists the above two types of people as litigants; the second view lists guardians as litigants; The third view lists the above two kinds of persons and guardians as co-defendants. The first and third view hold that persons with no capacity for civil conduct and persons with limited capacity for civil conduct can be litigants, while the second viewpoint holds that they cannot be litigants. The author thinks that the purpose of guardian system is to protect the above-mentioned subjects from effectively safeguarding their legitimate interests due to lack of sufficient identification ability. The guardian's duty is to supervise and protect the legitimate rights and interests of the abovementioned subjects, and he is not a ward, neither replace the ward as a litigant. "General Principles of Civil Law" stipulates that guardians bear civil liability is on the basis that they fail to effectively supervise and protect their ward, but do not believe that they have the qualification to replace the ward as a litigant. The "Civil Code" does not introduce Article 133 of "General Principles of Civil Law", but the "Civil Code" stipulates the guardian as the legal representative of the ward, and the "Civil Procedure Law" also stipulates that the person without legal capacity should be sued by his guardian as the legal representative, which also confirms the author's view that the guardian cannot replace the person without legal capacity or the person with limited legal capacity as the litigant. Guardians are only the subjects who assist persons with no capacity for civil conduct and persons with limited capacity for civil conduct to conduct civil litigation, exercise legal rights and perform legal obligations. Individual business should take the operators registered in the business license as the parties. Individual peasant household should take the farmer as the parties.

\subsubsection{Legal Obligations Determined in the Civil Legal Documents}

Civil legal documents include civil judgment documents, payment orders, arbitration documents and notarized creditor's rights documents with enforcement effect. According to the classification of litigation, it can be divided into three categories: action of performance, action for confirmation and action for alteration. [5] The action of performance refers to the action that a party requests the people's court to order the other party to act. The payment judgment determined according to the action of performance is a legal document that determines the substantive rights and obligations between the parties and orders the parties who have obligations to perform certain obligations. This kind of legal documents can be applied for enforcement. Therefore, the civil legal judgment referred to in this paper refers to the civil judgment, mediation and ruling made by the people's court which has the obligation of payment. In addition, the payment order made by the people's court in the supervision procedure, the arbitration book with payment obligation made by the arbitration institution, and the notarized creditor's rights document made by the notary office which gives enforcement effect according to law are all mandatory. The action of confirmation and the action of alternation are only the confirmation or alternation of a certain kind of legal relationship, but should not apply for mandatory.

\subsubsection{The Person Subject to Enforcement Should Be a Civil Obligor Who Has the Obligation of Payment}

Civil litigants include natural persons, legal persons and unincorporated organizations. Through the judgment of the people's court, or the ruling of the arbitration institution, or the notarial documents given the enforcement effect by the notary organ, the parties to the civil litigation should bear the legal obligation to pay and become civil obligors. Only this kind of subject has the basic conditions to become the executor.

\subsection{The Person Subject to Enforcement Is a Civil Obligor Who Has Entered the Executive Procedure by the Obligee}

The person subject to enforcement is the party who has the obligation to pay civil legal documents and enters the execution procedure. The parties must fulfill the legally effective civil judgments, conciliation statements, rulings and other legal documents that should be executed by the people's courts. If one party refuses to fulfill, the other party may apply to the people's court for execution. If one party fails to perform the award of an arbitration institution established according to law, the other party may apply to the people's court with jurisdiction for enforcement. If one 
party fails to perform the creditor's rights documents that have been given compulsory enforcement effect by the notary office according to law, the other party may apply to the people's court with jurisdiction for enforcement. The aforesaid civil obligor who has the obligation to perform the legal documents should become the person to be executed in the execution procedure upon the application of the other party.

\subsection{The Person Subject to Enforcement Who Is Included in the Scope of Disciplinary Action for Dishonesty}

The civil obligor is not included in the dishonest person after becoming the person subject to enforcement. After entering the execution procedure, the person subject to enforcement has fulfilled the payment obligation determined by his legal documents and will not be included in the list of dishonest persons. The people's court should be included in the list of dishonest executors, specify the scope of credit punishment, and make negative provisions for those executors who should not be included.

\subsubsection{The Scope of the Enforced Person Who Is Included in the Disciplinary Punishment for Dishonesty}

(1) The person subject to enforcement should have the ability to perform but refuses to perform

The person subject to enforcement often has the ability to fulfill the payment obligation determined by legal documents, but he is subjectively unwilling to fulfill the obligation. Which should include two types: should have the ability to perform but refuse to perform the obligations determined by the effective legal documents, and evading execution by means of false litigation, false arbitration or concealing or transferring property. [6] The first case is that the person subject to enforcement has the ability to execute, and refuses to perform by negative omission when the people's court issues a notice asking him to perform his obligations. In the second case, the person subject to enforcement takes measures to refuse to perform. Including the debtor conspiring with others to create false litigation through the people's court or arbitration institution, setting debts for himself through false arbitration or changing his own property into other people's property through confirmation litigation and change litigation, so as to avoid the property execution. The person subject to enforcement will also hide and transfer the property available for execution from being discovered by the people's court, so as to achieve the effect of evading execution.

(2) The person subject to enforcement obstructs or resists execution by means of forgery of evidence, violence, threats.

Whether the person subject to enforcement has the ability to perform does not prevent him from being the object of disciplinary action for dishonesty because he has obstructed or resisted execution by means of forgery of evidence, violence and threats. Under such circumstances, the person subject to enforcement may also bear criminal responsibility for his behavior in addition to being punished for dishonesty.

(3) The defendant violated the main measures in the

\section{execution procedure}

After entering into the execution procedure, the person subject to enforcement should truthfully report his personal property as required by the people's court. If the person subject to enforcement violates the property reporting system and refuses or fails to report his personal property truthfully, he will be included in the disciplinary list for dishonesty. According to "Several Provisions on Restricting the High Consumption and Related Consumption of the Executed Person formulated by the Supreme People's Court" [7], if the person subject to enforcement fails to fulfill the payment obligations specified in the effective legal documents within the period specified in the notice of execution, the People's Court may issue a high consumption restriction order to restrict its high consumption and related consumption which is not necessary for living or business. When the person violates the order, it will be included in the scope of the people who default on their court orders. At the same time, the people's court should take measures to restrict the consumption of those who are included in the list of dishonest executors for dishonesty. [8] During the execution, both parties can reach an agreement through selfreconciliation. After the settlement agreement is reached, the original legal documents will no longer be executed, and the person subject to enforcement should fulfill his obligations according to the settlement agreement. If the person subject to enforcement fails to perform the settlement agreement, the applicant may apply to resume the execution of the original legal documents. If the executor fails to perform the settlement agreement without justifiable reasons, it is not only against honesty and credit, but also has the intention of deliberately delaying the performance. The person subject to enforcement will also be included in the scope of the person subject to enforcement because of this behavior.

\subsubsection{The Person Subject to Enforcement Who Is Not Included in the Scope of Disciplinary Action for Dishonesty}

(1) The person subject to enforcement provides sufficient and effective guarantee

Although the enforced people has no real property for execution in the execution stage, it can provide guarantee for paying off the debts determined by the effective legal documents with the property rights that can be realized in the future, or a third party with solvency can provide guarantee for the executor to perform the debts. Under such circumstances, the rights and interests of the applicant can be effectively protected, and the enforced person may not be included in the scope of the enforced person for dishonesty.

(2) The property that has been sealed up, detained, frozen and other measures is sufficient to pay off the debts determined in the effective legal documents

The parties can apply for preservative measures against the other party's property at all stages of civil litigation. After entering into the execution procedure, the people's court will also take preservation measures such as sealing up, detaining and freezing the property of the person subject to 
enforcement. When the property value of the person subject to preservation measures is greater than or equal to the debt determined by the effective legal documents, the people's court may realize the creditor's rights of the applicant by auction, sale or deduction of the above property. In this case, no matter whether the executor is willing or not, the creditor's right of the applicant will be realized, so it is not necessary to include the executor in the enforced person for dishonesty.

(3) The enforced person should not be enforced according to law in case the execution order is later

There are multiple executors in the case, and different performance orders may exist because of their different legal status. In this case, if the former party has the obligation to perform, it should be performed by the former party. Before the execution measures of the executor who performed the obligation first have not ended, the executor who performed the obligation later can defend after performing the order, and the people's court should not take execution measures against him. Therefore, this kind of executors should not be included in the scope of dishonest executors before they should fulfill their obligations.

(4) Other circumstances that do not belong to that should have the ability to perform but refuse to perform the obligations determined by the effective legal documents

This item is a generally transparency provisions. The purpose of disciplining the enforced person for dishonesty is to urge the enforced person who has the ability to fulfill his obligations. In reality, the executors' performance ability is different due to their living conditions and economic ability. Although some executors are willing to fulfill the payment obligations determined in the effective legal documents, they are unable to perform due to various reasons. In this case, including it in the list of dishonest persons lacks the significance of this system.

(5) The person subject to enforcement is a minor.

Most of minors themselves do not have independent property, are not persons with full capacity for civil conduct, and do not have full capacity for litigation, so they are not included in the scope of dishonest persons.

\section{Procedures, Measures and Relief Channels of Being Included in the Enforced Person for Dishonesty}

\subsection{Procedures for Being Included in the Enforced Person for Dishonesty}

After entering the execution procedure, the people's court will issue written materials such as property report notice and execution notice to the person subject to enforcement. In the notice of execution, the risk warning about being included in the list of dishonest executors will be stated. At the same time, the people's court will check and control the bank deposits, real estate, vehicles, electronic payment accounts and other property of the executor, and take measures such as sealing up, detaining and freezing the discovered property of the person subject to enforcement. In addition to completing the declaration of property, the person subject to enforcement should also go to the people's court to accept the conversation at the appointed time and state his opinions on fulfilling the obligations determined by the legal documents. After the completion of the above procedures, in case the executors should be included in the list of dishonest executors, the applicant may apply to the people's court for inclusion in the list of dishonest executors. The people's court may also include the enforced person in the list of dishonest executors with its own functions and powers. In case the applicant applies to include the enforced person in the list of dishonest executors, the people's court should examine and make a decision within fifteen days from the date of receiving the application.

If the people's court decides to include the enforced person in the list of dishonest enforced persons, it should make a written decision, which should specify the reasons for including the list of dishonest enforced persons. Time limit for inclusion should be specified if necessary. The written decision should become effective upon issuance date of such document. The executors who are included in the scope of dishonest executors will also be restrict its high consumption taken by the people's courts. The people's court should also serve the written decision and the high consumption restriction order on the applicant and the enforced person. After the people's court makes the above-mentioned decision and high consumption restriction order, it will publish the above information on the national credit information sharing platform and establish a joint disciplinary system for dishonesty, so as to jointly punish such people.

\subsection{Punishment Measures to the Person Subject to Enforcement}

Punishment on the dishonest behavior of the dishonest person is to improve the social credit system, form a social atmosphere of "praising honesty and punishing dishonesty", and make the dishonest executors feel the great deterrent of "dishonest at one place and being restricted everywhere", and urge them to fulfill their legal obligations. For this purpose, the National Development and Reform Commission, the Supreme People's Court, the People's Bank and other 45 agencies jointly signed the "Memorandum of Cooperation on Joint Disciplinary Measures against the Enforced Persons for Dishonesty" [9] in 2016, which stipulated the contents and implementing units of disciplinary measures for breach of trust. At the same time, the person subject to enforcement is also restricted from high consumption. The Supreme People's Court formulate "Several Provisions on Restricting the High Consumption of the Executed Person" also stipulates the specific content on restriction of high consumption.

\subsubsection{Disciplinary Measures for Dishonesty}

The disciplinary action against the dishonest executors involves all aspects of natural persons, legal persons and unincorporated organizations as the dishonest executors in the society, including qualification restrictions, behavior restrictions, capital quota restrictions, preferential policies restrictions, 
strengthening supervision and management, publishing information of dishonest persons, social honor restrictions, high consumption restrictions and criminal penalties. [10]

\section{(1) Qualification restrictions}

The information of the person subject to enforcement will become an important reference for the regulatory authorities to approve the establishment of relevant companies and industry access. This information will be the basis or reference for the examination and approval of the establishment of securities companies, fund management companies and futures companies, the registration of private investment fund managers, the establishment of commercial banks or branches and representative offices, and the examination and approval of participating in shares and acquiring commercial banks, as well as the reference for strict examination and approval in the pharmaceutical and food safety industries.

The person subject to enforcement will be restricted from setting up certain companies and industries. And also will be restricted from setting up financing guarantee companies, insurance companies, and engaging in industries such as production, operation and storage of hazardous chemicals, production and operation of fireworks and firecrackers, mine production, safety evaluation and other industries.

If the person subject to enforcement is a natural person, he will be restricted from engaging in certain occupations, including directors, supervisors and senior managers of financing guarantee companies or financial institutions. And being restricted to serve as directors and supervisors of wholly state-owned companies, directors and supervisors of stateowned capital holding or shareholding companies, and senior managers of state-owned enterprises. If they have already held relevant positions, they will put forward their opinions for no longer holding relevant positions. They may also restrict from registering as the legal representative of a public institution, restrict the recruitment (employment) of civil servants or staff of public institutions, as well as restricted from serving as the principal responsible persons and directors, supervisors and senior managers of production and business units. For those who have already held relevant positions should be changed according to the requirements of the prescribed procedures.

Other qualifications that will be restricted by the person subject to enforcement. If the person subject to enforcement is a domestic state-controlled listed company, the equity incentive plan should be suspended or the exercise qualification of the equity incentive object should be terminated. Restricting the enforced person from using of state-owned forest land projects; Restricting its application for key forestry construction projects; Restrict the dishonest executors from reporting state-owned grassland land occupation projects, and restrict them from reporting key grassland protection and construction projects; As well as restrict the person subject to enforcement from becoming a customs certified enterprise.

\section{(2) Behavior restriction}

The people subject to enforcement will be restricted from issuing corporate bonds or corporate bonds, and for persons with seriously behaviors, he will also be restricted from acquiring listed companies. The legal person or non-legal person organization of the person subject to enforcement issues bonds in the inter-bank market. Restricting participation as a supplier in government procurement activities, and restrict participation in transactions of stateowned property rights such as assets of state-owned enterprises and state assets.

Restrict the enforced persons for dishonesty from paying high premiums to buy insurance products with cash value as the legal representative, main responsible person, directly responsible person affecting the performance of debts, and actual controller of persons subject to enforcement for trust-breaking (enterprises and institutions). Restrict the person subject to enforcement who is a natural person from leaving the country.

\section{(3) Quota restrictions}

The information of the person subject to enforcement will be a prudent reference for the approval and management of foreign exchange quota and the financing and credit granting of financial institutions. In the examination and approval and management of qualified foreign institutional investors and qualified domestic institutional investor quotas, the status of dishonesty should be taken as a prudent reference and implemented by the Foreign Exchange Control Board (FECB). Guiding all financial institutions to inquire whether the intended credit recipients and their legal representatives, actual controllers, directors, supervisors and senior management personnel are dishonest executors during financing and credit granting, and strictly examine the intended credit recipients as dishonest executors.

Assist the person who is subject to enforcement to apply for subsidy funds and social security funds.

\section{(4) Restrictions from enjoyed preferential policies}

When implementing preferential policies such as investment, taxation, import and export, inquire whether relevant institutions and their legal representatives, actual controllers, directors, supervisors and senior management personnel are enforced persons for dishonesty, and make prudent reference when enjoying the policy.

(5) Strengthen daily supervision and inspection

The dishonest executors and the units with dishonest executors as their legal representatives, actual controllers, directors, supervisors and senior management personnel should be regarded as key supervision objects, should strengthen the daily supervision to increase the proportion and frequency of random spot checks, and may take administrative supervision measures according to relevant laws and regulations. They should carry out strict supervision on the import and export of goods, implement strict supervision when the person subject to enforcement handles customs clearance business, and strengthen the examination of documents and inspection of control.

\section{(6) Publish the information of the dishonest person}

Publicize the information of the dishonest enforced person to the public through the website of "Credit China", the enterprise credit information publicity system and major news websites.

(7) Restriction of social honor 
For organs, enterprises and institutions, social organizations or their leading members who are enforced persons for dishonesty, they should not participate in the selection of civilized units, and those who have obtained the honorary title of civilized units should be revoked. All kinds of dishonest executors should not participate in the moral model selection, and those who have won the honorary title of moral model should be revoked. If the person subject to enforcement for dishonesty is a lawyer or a law firm, he hould be restricted from participating in the award evaluation within a certain period of time.

(8) High consumption restrictions

Restrict the dishonest enforced person and its legal representative, principal responsible person, the directly responsible person who affects the performance of the debt, and the actual controller to carry out the following high consumption: non-life and work necessary consumption behaviors such as take the plane, soft sleeper of the train, all the seats on the G-series high-speed train, first-class seats on highspeed trains; Accommodation in four-star hotels and other highgrade and high-consumption hotels and hotels is limited to consumption in nightclubs and golf courses; Purchase real estate, land and other real estate; Participate in group tours organized by travel agencies and restrict them from enjoying other tourism-related services provided by travel agencies.

Restrict on the consumption in tourist enterprises such as resort area with tourist rating.

Restrict the persons subject to enforcement for dishonesty and their legal representatives, principal responsible persons, persons directly responsible for influencing debt performance, and children of actual controllers from attending high-cost private schools.

(9) Punishment for those who refuse to execute judgment or ruling

Where the person subject to enforcement for trust-breaking constitutes a criminal offence, he should be placed on file for investigation or prosecution for the crime of refusing to execute the judgment or ruling.

\subsubsection{High Consumption Restriction Order}

If the person subject to enforcement is a natural person, after being restricted from high consumption, the following acts of payment should not be allowed: when taking transportation, choose the second-class or above cabins of aircraft, train soft sleeper and ship; High consumption in hotels, hotels, nightclubs, golf courses and other places above the star level; Purchase real estate or build, expand or decorate high-grade houses; Renting high-end office buildings, hotels, apartments and other places for office; Purchase vehicles that are not necessary for business operation; Travel and vacation; Children attend in high-cost private schools; Pay high premiums to buy insurance wealth management products and other high consumption behaviors that are not necessary for life and work. [11]

If the person subject to enforcement is a legal person or a non-legal person organization, after being restricted from high consumption, the person subject to enforcement and his legal representative, principal responsible person, and persons directly responsible for influencing the performance of debts are prohibited from carrying out the above acts with unit property.

\subsection{Relief Measures After Being Included in the Scope of the Person Subject to Enforcement}

The enforced person who has been included in the list of dishonest executors who should not be included in the list of dishonest executors, whose recorded and published dishonest information is inaccurate, and whose dishonest information should be deleted, the enforced person may submit a written application for correction to the relevant enforcement court. The enforcement court should examine it within fifteen days from the date of receipt of the written application for correction, and if the claim is justified, it should correct it within three working days. If the claim is not justified, the decision should be rejected. If the person subject to enforcement refuses to accept the rejection decision, he may apply to the people's court at the next higher level for reconsideration within ten days from the date of service of the decision. The people's court at the next higher level should make a decision within fifteen days from the date of receiving the application for reconsideration. During the period of reconsideration, the execution of the original decision should not be suspended. [12]

Under the circumstances that the enforced person being included in the list of dishonest executors has fulfilled the obligations determined by the effective legal documents or the people's court has completed the execution, the parties have reached an execution settlement agreement and completed the execution, the applicant applies in writing to delete the dishonest information, the people's court examines and agrees to close this execution procedure, and the property of the executor is inquired more than twice through the network execution inspection and control system, and no property available for execution is found, as well as the applicant or other person fails to provide effective property clues [13], the people's court decides to suspend the execution of the dishonest executor due to trial supervision or bankruptcy procedure, the people's court decides not to execute it, and the people's court decides to terminate the execution according to law, the people's court should delete the dishonest information within three working days. [14]

\section{Shortcomings and Suggestions of the Disciplinary Measures of the Enforced Person's Dishonesty}

\subsection{Shortcomings Involved in the Measures}

\subsubsection{The Legal Provisions of Disciplinary Measures Are Still Incomplete}

It is only stipulated in Article 255 of the "Civil Procedure Law" that the person subject to enforcement can record his non-performance information in the credit investigation 
system and publish it through the media if he fails to fulfill the obligations specified in the legal documents. [15] Therefore, the inclusion of the person subject to execution in the trust-breaking list is in accordance with the provisions of this Article. At present, 45 ministries and commissions including the National Reform Commission and the Supreme People's Court have decided to take joint disciplinary measures against those who have been included in the list of dishonest persons in the form of a memorandum of cooperation, which may inconsistent with the provisions of Article 255 that other measures prescribed by law can be taken against the above-mentioned enforced persons. Except for Article 255 of the "Civil Procedure Law" and the "Memorandum of Cooperation on Joint Disciplinary Actions against the Executed Persons for Breach of Dishonest", there are only "Several Provisions on Publishing the List Information of the Executed Persons for Breach of Faith" and "Several Provisions on Restricting the High Consumption of the Executed Persons formulated by the Supreme People's Court, both of which are not within the scope of law. The inclusion of the enforced person in the disciplinary list of dishonesty has caused great restrictions on all aspects of social activities of the enforced person. At present, only Article 255 of the "Civil Procedure Law" is the legal norm to take disciplinary measures against the executors who are included in the disciplinary list of dishonesty, which does not explicitly stipulate the disciplinary measures for dishonesty. The legal basis of this measure is still insufficient. At the same time, the relevant documents that specify the joint disciplinary measures are not at the legal level, and the legal effect is still lacking. [16]

\subsubsection{The Relief Procedure of Disciplinary Measures Is Not Perfect}

"Some Provisions on the Publication of Information on the List of dishonest Executors" stipulate that the executors who are included in the list of disciplinary lists for dishonesty may apply to the enforcement court that took this measure for correction. This regulation specifies that the main body for the execution of corrective measures is the enforcement court, but it does not specify the specific examination departments and procedures of the enforcement court. The uncertainty of the specific responsible department may easily lead to the lack of basis for processing the application and the buck-passing among departments. If the applicant directly applies to the specific contractor, it will cause the contractor to be both a referee and an athlete, which will easily weaken the credibility. At the same time, there is no specific provision for the review procedure, which is easy to cause difficulties in reviewing the correctness of the original decision during reconsideration.

\subsubsection{Lack of Judicial Disciplinary Measures and Disciplinary Measures Against Foreigners in the Disciplinary Measures}

The existing disciplinary measures specifically involve finance, commerce, daily life and other aspects, while the judicial disciplinary measures only include criminal punishment, but lack of civil litigation rights. As the world's second largest economy, enterprises and individuals from all over the world are engaged in civil and commercial activities in China, and the number of civil litigation cases in China is increasing year by year. The disciplinary measures against these foreign enterprises and individuals for refusing to fulfill their obligations determined by the effective laws of Chinese courts only limit their access to foreign exchange, and their scope of punishment is relatively narrow, which makes it difficult to achieve the effect of disciplinary measures.

\subsection{Suggestions on Improving the Disciplinary Measures for Dishonesty}

\subsubsection{Formulate Specific Laws for Disciplinary Action Against Dishonesty}

We should formulate a set of perfect special laws and supporting measures for the credit punishment of the person subject to enforcement. As a measure to punish the enforced person who refuses to perform the legal documents with the ability to perform, credit punishment will have a great impact on the dishonest person in all aspects of social activities. Since the implementation of this measure, many people legally in debt have fulfilled their obligations, which has served the purpose of disciplinary punishment for dishonesty, and also enhanced the awareness of the whole society to consciously fulfill its legal obligations. At present, this measure only has Article 255 of the "Civil Procedure Law" as the legal basis, while the specific measures are determined by the memorandum of cooperation between departments and two regulations formulated by the Supreme People's Court. This resulted in the incomplete legal framework and weak legal effect of disciplinary measures against dishonesty. It should be an important foundation to set up a disciplinary law for dishonesty.

\subsubsection{Improve the Disciplinary Relief Procedures for Dishonesty}

It is also an important measure to protect the legal rights of the dishonest person. On the basis of the existing relief procedures, specific examination departments and procedures should also be specified. The author thinks that the written application for correction by the person who has broken the promise should be examined by the enforcement court. The enforcement court is responsible for examining the court's enforcement objection, which belongs to different departments from the court's executive board and is not easily influenced by the executive department, and it is familiar with the trial business and enforcement business, so it is more appropriate for it to examine and correct the application. At the same time, the review procedure should be open, which can be presided over by the judge of the enforcement court in the form of a hearing, both the executor and the executor should attend and express their opinions, and finally the judge will make a decision on the application. 


\subsubsection{Restrict the Civil Litigation Rights of Dishonest Persons}

When the person subject to enforcement for dishonesty constitutes the crime of refusing to execute the judgment or ruling, he will be punished criminally. As the most serious form of social punishment, criminal punishment is only applicable to the serious situation such as refusing to execute judgments and rulings in accordance with the provisions of the Criminal Law, and it is not easy and can not be applied to all the dishonest enforced person. In addition to criminal punishment, the civil procedure should also restrict the civil litigation right ability of the person subject to enforcement for dishonesty, which constitutes a three-dimensional punishment mode of social punishment in the bottom, civil punishment in the middle and criminal punishment in the upper. The author suggests that the people's court may not approve the exemption, reduction or deferment of legal costs when the person subject to disciplinary action for dishonesty asks the people's court for civil prosecution and claim for the lawyer's fee will not be supported.

\subsubsection{Restrict Foreigners Who Subject to Enforcement Executors from Entering the Country and Applying for Permanent Residence in China}

For foreigners who have been included in the person subject to enforcement, they may be prohibited from entering China for several years after leaving the country to fulfill their obligations determined by the effective legal documents. We should carry out the inspection to such foreigners strictly when applying for permanent residence in China.

\section{Conclusion}

\subsection{The Scope of the Enforced Person Who Is Included in the Scope of Disciplinary Action for Dishonesty}

Not all civil subjects can become the object of disciplinary measures for dishonesty. full civil capacity and civil litigation capacity of the civil subject is the primary condition for disciplinary measures against dishonesty. The minor should not be executed with disciplinary measures for dishonesty. The civil subject subject to disciplinary measures for dishonesty should also be the person who has the obligation to perform the payment, and under any of the following circumstances: (1) The person subjected to enforcement has the ability to perform but refuses to perform (2) The person subjected to enforcement obstructs or resists execution by means of forging evidence, violence or threat (3) The defendant violates the main measures in the execution procedure (4) The person subjected to enforcement provides a full and effective guarantee.

\subsection{Types of Disciplinary Measures and Relief Measures Against Dishonesty}

\subsubsection{Disciplinary Measures for Dishonesty}

Disciplinary measures against dishonesty include restrictions on high consumption and inclusion in the list of dishonest persons.

If the person subject to enforcement is a natural person, after being restricted from high consumption, the following acts of payment should not be allowed: when taking transportation, choose the second-class or above cabins of aircraft, train soft sleeper and ship; High consumption in hotels, hotels, nightclubs, golf courses and other places above the star level; Purchase real estate or build, expand or decorate high-grade houses; Renting high-end office buildings, hotels, apartments and other places for office; Purchase vehicles that are not necessary for business operation; Travel and vacation; Children attend in high-cost private schools; Pay high premiums to buy insurance wealth management products and other high consumption behaviors that are not necessary for life and work.

The disciplinary action against the dishonest executors involves all aspects of natural persons, legal persons and unincorporated organizations as the dishonest executors in the society, including qualification restrictions, behavior restrictions, capital quota restrictions, preferential policies restrictions, strengthening supervision and management, publishing information of dishonest persons, social honor restrictions, high consumption restrictions and criminal penalties.

\subsubsection{Relief Measures After Being Included in the Scope of the Person Subject to Enforcement}

The enforced person who has been included in the list of dishonest executors who should not be included in the list of dishonest executors, whose recorded and published dishonest information is inaccurate, and whose dishonest information should be deleted, the enforced person may submit a written application for correction to the relevant enforcement court. The enforcement court should examine it within fifteen days from the date of receipt of the written application for correction, and if the claim is justified, it should correct it within three working days. If the claim is not justified, the decision should be rejected. If the person subject to enforcement refuses to accept the rejection decision, he may apply to the people's court at the next higher level for reconsideration within ten days from the date of service of the decision. The people's court at the next higher level should make a decision within fifteen days from the date of receiving the application for reconsideration. During the period of reconsideration, the execution of the original decision should not be suspended.

\subsection{Deficiencies in the Disciplinary Measures Against Dishonesty}

The punishment system for dishonesty is incomplete in three aspects. First, the legal system is incomplete. The basis for disciplinary measures of dishonesty is Article 255 of the "Civil Procedure Law", but the article does not make clear provisions on punitive measures for dishonesty. The specific disciplinary measures are mainly stipulated in relevant provisions of the Supreme People's Court and joint 
memoranda between multiple departments. Disciplinary measures of dishonesty should have an important influence on the person subjected to enforcement. At present, there is a lack of legal provisions and no system of specific punitive measures, which is unfavorable to the development of punitive measures for dishonesty. Second, the relief procedures are not incomplete after the disciplinary measures against dishonesty. The Supreme People's Court only stipulates that the people's court should delete the person subject to enforcement from the list of truster or release its restriction on the high consumption, but does not stipulate the specific responsible department, so that it is easy to cause the buck passing between the departments of the people's court. Third, at present, the object of dishonest disciplinary measures is Chinese person, and there is still lack of effective disciplinary measures for foreigners who are included in the disciplinary measures for dishonesty.

Suggestions on perfecting the dishonest disciplinary measures. First, formulate a unified social credit law, so as to regulate the objects, types, procedures, relief channels and other aspects of the dishonest disciplinary person in the form of legal. Second, clearly stipulate that the enforcement court of the people's court should be responsible for the relevant relief work of dishonest disciplinary measures. Third, it constitutes three-dimensional punishment of which the social punishment at the bottom, civil punishment in the middle and criminal punishment at the top. If a person subject to enforcement who is included in the scope of punishment for dishonesty requests the people's court to exempt, reduce or postpone the payment of litigation costs in civil proceedings, the people's court may not approve, and the claim for the lawyer's fee should not be supported. Fourth, foreigners who have been included in the scope of dishonest persons subject to enforcement should be restricted from entering China and applying for permanent residence in China.

\section{References}

[1] Article 3 of "Civil Procedure Law of the People's Republic of China".
[2] Book One General Provisions of "Civil Code of the People's Republic of China."

[3] Yang Lixin: "Research on general part of civil code of the People's Republic of China" China Renmin University Press, page. 56 (2017).

[4] Tan Ying, Huang Yongguang: "A Study on the Norms of Guardian Liability-From the Tort Liability of Civil Code (Draft of the Third Deliberation)", "Journal of Guangxi Administrative Cadre Institute of Politics and Law", 2020, (1).

[5] Shen Ailing, Tian Kan: "Types of litigation and scope of application of limitation of action", "Seeker", 2004, (12).

[6] Article 1 of the" Several Provisions of the Supreme People's Court on Announcement of the List of Dishonest Persons subject to Enforcement".

[7] https://www.chinacourt.org/law/detail/2015/07/id/148347.shtml

[8] Article 1 of the" Several Provisions of the Supreme People's Court on Restricting High Consumption and Relevant Consumption of Persons Subject to Enforcement".

[9] http://www.gov.cn/xinwen/2016-01/28/content 5036834.htm

[10] http://czxxfy.hebeicourt.gov.cn/public/detail.php?id=300

[11] Article 3 of the" Several Provisions of the Supreme People's Court on Restricting High Consumption and Relevant Consumption of Persons Subject to Enforcement".

[12] Article 12 of the "Several Provisions of the Supreme People's Court on Announcement of the List of Dishonest Persons subject to Enforcement ".

[13] Article 10 of the "Several Provisions of the Supreme People's Court on Announcement of the List of Dishonest Persons subject to Enforcement".

[14] Article 11 of the "Several Provisions of the Supreme People's Court on Announcement of the List of Dishonest Persons subject to Enforcement".

[15] Liu Mingrui: "Perfection of the Protection Mechanism of the Rights of the Enforced Persons Who Lost Trust", "Journal of Shanxi Youth Vocational College", 2021, (3).

[16] Li Shuo: "The Legitimacy of the Joint Disciplinary Actions against Dishonest Persons and the Reinforcement of It-Take the Memorandum of Understanding on Taking Joint Disciplinary Actions against Dishonest Persons Subject to Enforcement as a Sample", "China Law Review", 2021, (1). 